\title{
Institutionally Generated Crises and the Challenges of Economic Integration in South-South Nigeria
}

\author{
Ebebe A. Ukpong ${ }^{1} \&$ Moses U. Ikoh ${ }^{2}$ \\ 1. Nigerian Institute of Social and Economic Research, Ibadan, Oyo State, Nigeria. \\ 2. Department of Sociology, Federal University, Lafia, Nasarawa State, Nigeria.
}

\begin{abstract}
In this paper we examined the challenges posed by institutionally generated crises on the economic integration plans initiated by the South-South geo-political zone of Nigeria. The overarching objective was to identify and provide a systematic analysis of the embedded crises, outline their consequential challenges and provide the public and policy-makers a guiding framework to redirect paradigms towards ending the crises. Using the theoretical lenses of the Cognitive Institutional Perspective (CIP) - a combination of Neoinstitutional theory and Cognitive theory - we explore the several features and complexes that influence the actions and reactions of the South-South Governors to the NBC new boundary regime and the pronouncements of the Supreme Court on the several cases of redress and interpretation that were before it. In order to end the face-off generated by the crises, we asked and answered three related questions drawing largely from documentary and media publication evidences. After discussing the challenges, we offer recommendations towards ending the crises. These include mediation by the South-South leaders, mediation by the South-South traditional Rulers, and intensification of effort toward the realization of the South-South economic integration to spur growth in the South-South States, among others.

Key words: Institutionally generated crises, Embedded crises, Economic integration, South-South geo-political zones, National Boundary Commission, Bakassi Peninsula, Cognitive Institutional Perspective, Oil wells.
\end{abstract}

\section{Introduction}

The South-South geo-political zone of Nigeria consists of 6 States of the Nigeria's federation. They are Bayelsa, Rivers, Akwa Ibom, Cross River, Edo and Delta, popularly recognized jointly by the acronym of BRACED States. Besides lying contiguously to each other, each State has several pockets of ethnic groups facing similar deprivation. This is in spite of the crude oil (referred to by the indigenes as the black gold) in their soil, and the many years of its exploitation by the Federal Government. Crude oil remains the singular reliable source of revenue for Nigeria and the South - South is the home to Nigeria's oil and gas. Several scholars have referred to the exploitation of crude oil in the region as the "oil curse" (Omeje, 2006; Akpabio \& Akpan, 2010; Inokoba \& Imbua, 2010). Analysts have also examined the deprivations that the natives face despite the huge revenue derived from their soil (Okonta, 2001, Ibaba, 2005).The consequences of these on militancy and crime have also received scholarly attention (Ikoh, \& Ukpong, 2013; Udoh, 2010). On the realization of these problems, the governments of the six States in the region decided to establish an economic integration agenda that would fast-track development, create wealth, employment, restore peace after several years of youth restiveness and militancy; and launch the region out of poverty into prosperity.

In an historic move in 2009, the first South-South Economic Summit was held in Calabar. It resulted in the establishment of the BRACED Commission, an acronym generated from the names of the six States in the region. The Commission is saddled with the tasks of ensuring the process of economic cooperation and integration among the South-South or BRACED States. In order to facilitate the achievement of the mission, several working groups were established with priority areas spanning through agriculture, environment, infrastructural development, human capacity development and industrialization. It signaled a resolution of rising expectation by the citizens, the political class and the Civil Societies. Five years into this bold initiative, very little seems to have been achieved. Ability to move the initiative from vision and strategies to action has been constrained by several institutionally generated crises. This study is not an evaluation of BRACED Commission but a simple analysis of significantly, current social forces around it with potentials to negatively influence development policies and programmes.

The mass media have made bold attempts in the past to report these crises either through features analysis or paid advertisement (Folaranmi, 2013; Ujah, Onoyume \& Oyadonga, 2012; Chukwu, 2011) but not in a systematic manner. A cursory scan of the national newspapers in the last two years reveals some events that resulted in face-off amongst the Governors in the South-South geo-political zones. Such events include the delineation of States boundaries by the National Boundary Commission (NBC) and the resultant (re)shifting of oil wells and the Supreme Court judgments that followed the different disputations. Several strategies adopted 
by the States including appeal to public sentiments, and seeking of redress in the apex court to revert to status quo received several media colouration. These heightened tension among the States and further strained the relationship between the political class and the bureaucrats and between kith and kin in the affected states. Beyond these media reportage, little or no attempt has been made to examine the consequences of these crises on the avowed dream of the South-South economic integration and cooperation, and the challenges that must be overcome for the South-South plans to be realized.

Each of these two categories of events identified here has its unique situational and contextual features, but they share common characteristics. They are crises generated by the Federal institutions: the NBC, the National Planning Commission (NPC), the Supreme Court, and others but impacting on a nascent regional institution and its development initiatives. In Coser's (1977) analysis, institutions are seen as instruments for the realization of power and hegemony, but can help in stabilizing prevailing inequalities. In his incisive analysis of crises, Stern (2003, p.3) referred to crises as "the great storms of political life". He likened crisis to the "hurricanes, tornadoes, and tidal waves" that have both negative and positive consequences. Crisis can wreck destruction, thus frustrating the realization of plans and targets. It may also clear the air, breaking up logjams and deadlocks and thus paving the way for change. But beyond such analysis, crises are associated with high impact factors, consequential choices and sometimes tough political dilemmas (King, Keohane \& Verba, 1994). It can involve situations where cherished national values are at stake (Schmitt, 1996). In such instances, the resultant consequences can stall development especially when stakeholders in the crises are unable to handle them.

Using the theory of Cognitive Institutional Perspective (CIP), we observed that several complexities are involved in crisis situation decision-making. Crises are often characterized with unexpected political events, some with time limitations, for decision to be made. Such limitations often push policy-makers and administrators to take non-routine decisions, with consequential error of over-reaction. Beside, these institutional decisions may be misunderstood. Ability to reappraise these decisions and reactions taken in the "heat" of the crises may force a rethink that could correct errors of overreactions. This explains the task of this paper, and the significance becomes very compelling. Studies of crises and consequence of decisions made during the period of the crises can provide derivative lessons (Stern, 2003). Apart from providing opportunity to learn, adapt and enter into a more sustainable pathway (Herrfahrdt-Pahle \& Pahl-Wostl, 2012), it could enable policy-makers to redirect paradigms, mechanisms, and structures that led to the crises and hopefully end the face-off generated by the crises. In order to achieve these objectives, the paper provides answer to three related questions:

i. What historical and institutional contexts exist for these crises?

ii. What effects have these crises on the developmental plan of the South-South region?

iii. How can errors in decision-making and or reactions during the South-South crises be corrected to create room for cordial relationship in order to realize the plans of South-South economic integration?

The rest of the paper is organized in themes. After a brief background of the study area and the crises is presented, the paper explains the methodology adopted for data collection, and provides conceptual explanation along with literature review and guiding theory. In the next theme, discussions that seek to answer the questions raised in the problem definition follow. The paper concludes with a summary and recommendations.

\section{Study area and background of crises}

The South-South geo-political zone of Nigeria is located in the Niger Delta Region (NDR). It comprises the six States of Bayelsa, Rivers, Akwa Ibom, Edo, Cross River and Delta that make the acronym, BRACED, as its members. Each of the States lies contiguously to each other. This nearness and historically long time interaction enhance shared values and custom and enforce the concept of brotherhood among them. Perhaps, more than the shared custom and values is the shared deprivation of her indigent population that constituted the minority tribes in the then Eastern and Western regions of Nigeria.

The South-South States are predominantly coastal and open directly to the sea. This geographical location technically accords them the littoral status in relation to offshore oil wells and entitles them to lay claim to resources in their maritime territory up to 200 meter isobaths. The derivation principle enables States endowed with crude oil to share $13 \%$ of the revenue derived from crude oil monthly. All the States in the region therefore depend on oil revenue to finance their socio-economic and political development.

Before the International Court of Justice (ICJ) judgment that ceded the entire Bakassi Peninsula to the Republic of Cameroun on 10/10/2002, the Western part of it was controlled by Cross River State. This area constituted the Bakassi Local Government Area, duly recognized by the Federal Constitution of Nigeria. But having lies at the Cross River estuary, access to Bakassi was possible through a maritime corridor created out of Akwa Ibom maritime territory. The ICJ ruling of 10/10/2002 on the land and maritime boundary case between Cameroun and Nigeria wiped out what used to be the estuarine sector of Cross River State, thus denying the State a seaward boundary (Chukwu, 2012). Influenced by this ruling, the Akwa Ibom State Government 
approached the National Boundary Commission (NBC) and the National Planning Commission (NPC) to request that the maritime corridor created for Cross River State out of Akwa Ibom maritime territory should be closed since the need served by the corridor was no longer in existence. In doing so it would enable Akwa Ibom to access the maritime territory that was shifted into Cross River State as a result of the corridor. That request resulted in a new boundary adjustment.

The new boundary regime readjusted boundaries between the States in the region, using historical connections rather than political considerations. But the readjustment was not without consequences as some States lost portions of land and maritime territories, while others gained along with the oils wells and field located in them. For instance, Akwa Ibom was able to access 76 oil wells that were shifted into Cross River State as a result of the creation of the maritime corridor. Eighty six (86) oil wells from Akwa Ibom were also shifted to Rivers State, while 68 oil wells from Rivers State were relocated to neighbouring Abia State, in the South East region. In similar fate, oil field and wells located in Oluasiri went to Bayelsa State.

The presentation of the new boundary delineation on $9 / 6 / 2009$ by the NBC was greeted with mixed reactions. While some commentators regarded the NBC's action as boundary governance reforms that has shifted from the "command-and-control paradigm" of the Obasanjo presidency to a more participatory one under President Musa Yar' Adua administration (Chukwu, 2011), others argued that the NBC had compromised their role and are being manipulated to serve the interest of some people in power (Ujah, Onoyume, et al, 2012). Such reasoning resulted in accusation and counter accusations. For instance, Cross River State challenged the shifting of the 76 oil wells to Akwa Ibom in the Supreme Court. Similarly, Akwa Ibom went to the Supreme Court to seek interpretation of her border lines with River State, while Rivers State challenged the delineation of her boundary with Bayelsa in the same Court. All the cases were ruled in favour of the respondents. While Rivers State had her case against Bayelsa struck out by the court, Cross River was denied the status of being an oil producing State. The Supreme Court also ordered Akwa Ibom to respect the boundary delineation between her and River State and return the 86 oil wells.

The impact of the loss of oil wells and fields on revenue created a huge funding gap on projects and programmes, especially on existing budget. It introduced crises that started with war of words, then face off and actions that threaten existing convergence cord. The Crises affecting the South- South States are therefore related to its position in the Nigeria's oil driven economy. It has a big price tag - unemployment, social tension, and the loss of a collective voice by the South- South States on matters affecting them. An additional worry is also emerging on the lack of renewed commitment and financial support to the BRACED Commission, the brain child of the South-South Economic Summit (SSES).

\section{Methodology and data sources}

The paper drew evidence from documentations and publications concerning institutionally generated crises in the South-South Nigeria. Theoretical construct and previous research findings are deployed as a way of throwing more light into the work. The data source, therefore, consists of news report drawn from both print and broadcast media, scholarly works, and journalistic publications. Emphasis is placed on government publications as authoritative source and evidence on existing crises.

\section{Conceptual explanation, literature review and theory}

The word, "crisis" has evoked many meanings in social science and health literature and would need to be operationalized to provide contextual meaning in this work. Here we abide by Stern's (2003) suggestion that a rigorous specification that link "crisis" to explicit referent would help to correct misrepresentation. Following such suggestion, crisis becomes an experience by someone, an individual (Habermas, 1973), a group or an organization (Janis, 1982). It can also be experienced by a society or a State (Bryder, 1998). Crisis situation may "threaten actors bound up in a bilateral relationship or a system such as a regional sub-system, or the international system at large" (Stern, 2003, p. 5).

In Hermann's (1972) analysis, crisis represents a situation that threatens high priority goals of the Decision Unit. It not only surprises member of the Decision Unit by its occurrence, but also restricts the amount of time available for decisions to be taken. The International Crisis Behaviour Project (ICBP, 1988, p. 17) affirmed this argument, and observed that a crisis situation confronting a State would raise "three necessary and sufficient conditions - a threat to basic values, a finite time for response, and a high probability of involvement in hostilities". Here basic values consist of "core values", and "high priority values". While core values has to do with the survival of the State and its citizens (for instance a threat to revenue base, and hence projects and key government programmes and projects), high priority values are concerned with ideological or material interest as defined by decision-makers at the time of the specific crisis. Stern (2003) argued that the high priority values may not be unconnected with decision-makers concern for their reputation and ability to remain in power. In synthesizing the definition, he outlined three perceptions that influence decision-making during crisis situation, to include threat to basic values, urgency, and uncertainty. The perception that the crisis situation can 
cause policy harm, suggests a direct influence on decision-makers' reaction which may heighten the tension of the crisis.

Beyond the definitions, Richardson (1994), Green and Shapiro (1998), offered interpretation on the nature of threat posed by crisis to the "basic values". Certain causal mechanisms including economic, drives political behaviours and can become more salient in crisis decision-making. Even when associated economic crisis may be short-termed, the threat to material and political values, especially when it has to do with resource shortage and ego boosting may linger (Maruyama, 1990). Such interpretation accounts for the height that institutionally generated crises have reached in the South-South Nigeria. The revenue accruable to each State in the region from the Revenue Mobilization and Fiscal Commission (RMAFC) depends on the number of functional oil well located in the State. The loss and or gain of oil wells affect States' revenue base, and hence budget, infrastructural and social development.

The crises generated by the new boundary governance by the NBC have resulted in disaffections between the South-South States. Unfortunately all the States in the region have collective threats in environmental crisis, youth unemployment and poverty, but very little attention and interpretation is being given to these collective threats. Environmental crisis as demonstrated in acid rain, oil spillages, depletion of aquatic lives, etc, due to many years of oil exploration and exploitation with damaging threats to biological values (human health, eco-system- air, water - food production) is losing the collective voice. Link roads in the region are in deplorable condition, and the water ways are volatile. In the face of these embedded crises and attendant disaffections, the open threats become largely exacerbated.

\section{Theorizing Institutionally Generated Crisis}

In sociological theory, three prevailing interpretations are given to institutions. These include interpretations influenced by the functionalist perspective, Marxist-conflict oriented approach, and Neoinstitutionalist approach. In the traditional Durkheimian's and Parsonian's argument, institutions are seen as parts of the social system that perform separate and distinctive functions for the stability of the whole. Contrary to this argument, the Marxist-conflict approach believes that "conflict and inequality are inherent in modern society (Coser, 1977) and so institutions would not perform equally well for all members of the society (Schaefer, 2008). In many instances, institutions have become instruments for the realization of power and hegemony, and thus help in stabilizing prevailing inequalities.

The position of the Neo-institutionalist theory is that institutions are important for the enactment of action routine (Powell \& DiMaggio, 1991). In this sense institutions are seen as unburden individuals and make their societies predictable. Since institutionalized actions are seen as normal routines, they are often not subjected to questioning. Society members are expected to get adapted to and carry them out as role expectations of the society (North, 1990). In this thinking, Giddens (2009) warned that there must be trust and transparency to enable the existence and functionality of social institutions. Such warning suggests the disaffections that society members are experiencing as a result of some institutionalized routine actions.

Attempt to explain society members' disaffection as result of institutionally generated crisis has resulted in the emergence of Cognitive Institutional Perspective (CIP) - a combination of neo-institutional theory in Sociology and cognitive theory in Psychology (Nisbert \& Rose, 1980). This interdisciplinary approach combines a wide scope and accuracy that enhance correct predictions and explanation of emerging crises.

According to Fiske and Taylor (1991), the CIP has 5 distinctive features (human subjectivity, belief/expectation, limited information and processing capacity, cognitive motivation, and stress) associated with the cognitive revolution, and 6 features (group network and organization, institutional structures, subjectivism, history and inheritance/ politics and communication, as well as symbolism) associated with neoinstitutionalism. These features constitute the assumptions or organizing principles within which the paradigm shift in society members' reaction to institutional routine action can be explained.

The cognitive explanation focuses on the subjective nature of human behavior which influences the interpretation of events. For instance past experiences can exert significant influence on interpretation. In similar way, expectations and belief can shape perceptions. Such subjectivity becomes highly elevated where parties in crises have limited information processing capacity. The inability to monitor and analyze highly complex physical and social environment can pose problems in crisis decision-making (Purkitt, 1992). Even when information are available, the stream may overwhelm the human capacity to absorb and make use of them (Stern, 2003). In many cases stakeholders may resort to selective use of incoming information, and in the process of filtering them may miss the important ones. Political fenders in the name of "Personal Assistants" and "Advisers" sometimes fence off their Principals from having access to most useful and reliable information.

The interface between motivation, emotion and information processing is influenced by individual differences in information processing. Based on ones motive, information can be grossly distorted, and when such distorted information influence decision-making, it can result in policy failures. Psychological stress is also acknowledged as a factor in crisis decision-making. According to Lebow and Stein (1994, pp.: 331 - 338), such 
stress ranged from "lack of time/overload, threat of loss generating interval conflict, and threat of loss exacerbating existing interval conflict". These different types of stress may have differing effects on the capacity of decision-makers.

The neo-institutional inputs in the CIP recognize social formations such as groups, networks, and organizations and their roles regarding reaction to institutional routine actions. These social formations provide platforms which individual decision-makers are embedded and used in performing their role in the society. Added to these exist institutional structures which determine policy decision. Although this suggests diverse interest, which would influence inputs, historical context also exerts impacts on policy making and decisions. Historical experience and precedent play important role in shaping how a particular crisis is perceived and handled. Herrfahrdt-Pahlet and Pahl-Wostl (2012, p. 8) observed that "path dependence is not only relevant in terms of the relationship between crisis and historical context, but also in terms of the sequence of events within a given crisis".

The neo-institutionalism component also explains the highly politicized nature of organizational life of government, which influence decision-making. In many instances, "decisions are not taken as instrumental action on the basis of shared and uncontested collective goals, but as part of ongoing individual, factional, group, or organizational competition" (Vertzberger, 1980, p.21). Such competition may be to promote political career, and or personal ambition (Stern, 2003).

The strengths of CIP are therefore found in its pervasiveness and ability to provide explanation for crises generated by institutionalized routine actions. Prior history creates cognitive and collective dispositions toward perceiving and responding to crisis. But problems definitions and value prioritizations are not always objectively assessed. It is often skewed favourably to those exercising political and administrative authority. When a crisis is triggered, it creates a situation of heightened stress for decision makers and government institutions, and may be managed with lesser degree of skill (Geva \& Mintz, 1997). This is because the interplay of power, interest and reason often shape the outcome. Even when decision makers need the inputs of experts to take decision, situation of uncertainties could create room for divergent interpretation. Decision-making in crisis situation are therefore influenced by a complex conjectures of reasons, power, and interest, which may or may not yield result that benefit a greater majority (Janis, 1989).

\section{Discussion}

Institutions are important for the enactment of action routines. But such action routines (important as they may be) are no longer followed without questions. Lack of trust and the quest for transparency - a key component in governance reforms - influence society members' adaptation to institutionalized routine action as well as their role expectation. Institutions in the realm of the National Boundary Commission, the National Planning commission, and the Supreme Court operate in the myriad of society setting either in effort to repair the social fabric or to stabilize it. In either of these functions or more, tensions and are created and surprise unacceptable changes are perceived as crisis. Decision-making in a crisis situation has evidence of dramatic behavior (Janis, 1989). Such behavior seems difficult to understand on the basis of cursory analysis (Stern, 2003). For a systematic analysis of institutionally generated crisis in South-South Nigeria, the research questions posed at the introductory segment of this paper will be answered in the course of this discussion, guided by the theoretical lens adopted for the study.

Question 1: What historical and institutional context exists for these crises?

The CIP adopted for this study identifies two dimensions of temporal complexity of history associated with crisis. These include the diachronic and synchronic (Stern, 2013). While diachronic refers to the pre-history of the crisis, synchronic complexity refers to the present history. The existence of these dimensions suggests that crises decision-situations and the reactions that followed are not only influenced by what happened in the past but also by what happened in the present.

The decision by the NBC to adjust the boundary between the States in the South-South region has been justified by the ICJ judgment and the excision of Bakassi Peninsula from Nigeria to Cameroun (Sagay, 2004). Other scholars have also argued that the NBC action was to correct the "command-and-control" strategy adopted by the Obasanjo Presidency reforms (1999 - 2007; Chukwu, 2011). For instance, Ujah, Onoyume and Oyodongha ( 2012), have argued that the crisis between Cross River and Akwa Ibom was affected by lack of proper analysis of the historical background that influenced the delineation of the boundary. An earlier political solution had allowed some portion of Akwa Ibom to remain in Cross River so that Cross River can have access to Bakassi Local Government Area, which is in Cross River State. After the World Court decision that conceded Bakassi to Cameroun, it was not unexpected that Akwa Ibom would want to reclaim their maritime territory. But no boundary adjustment in Nigeria has been perfect. For instance, Opobo and Nkoro were part of the then South Eastern State during the General Yakubu Gowon era. But in 1976, the Nasir Boundary Commission ceded Opobo and part of Nkoro to Rivers State, allowing part to remain in South Eastern State (Now Akwa Ibom). The 
same poor demarcation is the root cause of the dispute between Rivers State and Bayelsa State in the Soku section with its oil wells.

Official pronouncements formally acknowledge the existence of embedded crises generated by institutional (in) actions in the realms of boundary adjustment and judicial pronouncement. They are said to have spawned series of campaign of calumny, blackmails, incitements which threaten and strain historical, cultural and age-old brotherly ties as well as weaken the administration of justice. Efforts at making peace between states but being rebuffed are recorded. The loss of statutory derivation revenues are reported as crisis indicator, especially when said to contravene section 162(2) of the 1999 Constitution of Nigeria. The loss of oilbearing state status is painfully conflict-laden. For instance, Cross River State was regarded as a littoral state in 2005 through executive Presidential fiat on the recommendation of NBC but lost that status subsequently by the pronouncement of the Supreme Court (AKS,2012).

Question 2: What effects have these crises on the developmental plan of the South-South region?

Like any other State in the country, the South-South States generate most of her revenue from the monthly Federal revenue allocation. Functional oil wells in each of the South-South States remain the yard stick for additional revenue based on the 13\% derivation principle. In the case of Cross River and Akwa Ibom States, the boundary adjustment shifted 76 oil wells in Cross River to Akwa Ibom. Economically speaking, this exerted a huge negative impact on revenue accruable to Cross River; it constituted revenue denial from the $13 \%$ derivation revenue.

The first major reaction by many of the States was to seek redress in the Supreme Court, thus questioning the routine activities of the NBC. Benefiting States were suspected by the losing States to have lobbied the NBC to embark on the boundary adjustment. These accusations and counter accusations resulted in name calling. By the time the Supreme Court verdicts were delivered and the back-up decisions by the RMAFC effected, revenue allocation to many States was affected. A host of new problem arose. In the face of decline in expected revenue, it became difficult to fund budgetary allocation, execute projects that had been initiated and fund programmes that target social and infrastructural development. In particular, Cross River was forced to operate under heavy stress in budget cut and implementation of projects and financial obligations. Lack of revenue to fund development projects suggests problem complexity which cut across all other complexities.

The difficulties experienced by each state found collective expression at the sub-national level of the South - South geo-political zone. The proceedings of the First and Second Economic Summits of the Zone elaborately outline the development vision, goals, programmes and strategies of the South -South Nigeria, especially in the context of economic integration which emphasizes cooperation than competition among the six states (Ukpong, $2009 \&$ 2012). Assessing the progress, four years after inception, indicate the subtle impact that the embedded crises have adversely made on the realization of goals of the BRACED Commission (BC, 2013).

The crises, which came to the fore shortly after the widely acclaimed successful First South - South Economic Summit in 2009, have created stalemate and stalled the development programmes of the BRACED Commission being demonstrated in the inability of the BRACED leadership to meet in 16 months. On the other hand, the 'stalemate is characterized by political and personality differences and suspicions' which foster distraction. State officials do not show strong commitments to the cause of the Commission; a setback derived from the weak support given by Governors of the BRACED States. The absence of broad vision, ostensibly blurred by competition, is reported as well as the failure to present a collective leadership and engage the Federal Government on a number of issues, including the East - West Railway Line, the region's sea ports, etc. Timelines are falling behind. For instance, the Summit which was expected to be held annually has been "organized only twice within the interval of three years" (BC, 2013,pp 9-10).

Question 3: How can errors of decision and or reaction be corrected to create room for cordial relationship in order to realize the plans of South-South economic integration?

The question that has been asked by public commentators (Folaranmi, 2013; Omotoso, 2012) and posed by this paper is how the crises motivated by NBC decision was allowed to degenerate to a face-off in the region, in spite of the seemingly cultural and political understandings in the region. For instance, the governor of Cross River State is the Chairman of the South-South Governors' Forum, and in that capacity remains the leader of the BRACED States. In the face of the crises he is said to have rebuffed initiatives for a political solution that could have prevented the escalation of the crises (AKS ,2012). Interestingly, five of the six States in the region are in the same political family. As we found in the literature, crisis has in its fold several threats that affect one or more values. In this context several complexities exert influence on actions and reactions. These complexities need to be weighed and reweighed, and in many cases crisis presents very short time frame for decision-makers to think and make elaborate consultation; action has to be taken.

Within the theoretical lenses adopted for this discourse, three types of complexities commonly associated with crisis episode (Snyder, Bruck \& Sapin, 1993) can be used to answer this question. These include 
political, institutional, and informational complexities. Political complexity requires the ability to balance long term imperatives. For this purpose future crisis episode must be deterred and legal accountability with short term interest attained. Beyond these, crises tend to affect multiple actors and or stakeholders with collective sentiments. In this context not only government officials and bureaucrats but also those in the private sector and political opposition would be interested on how the crisis is prosecuted. These considerations may have influenced the decision of States to seek redress in the Supreme Court, rather than go for political mediation.

The institutional complexity has both horizontal and vertical form. When viewed horizontally, institutional complexity will concern several agencies at the same level of government - the Attorney General and Ministry of Justice, which inputs are required in crisis situation. The vertical dimension involved actors and stakeholders across levels of government. These include especially the Executive, the House of Assembly, Senators and House of Representative members from the State, Local Government Chairmen, and politicians at several levels, who see themselves as having a stake in the crisis at hand. Each of these stakeholders holds different perceptions which influence their understanding of the crisis and how to find solution.

Beside political influence, informational complexity constitutes constraint to cognitive processing and hence bargaining efforts. Information regarding the nature of the crisis may have been understood but the "motivations, capabilities and dispositions of actors and stakeholders" (Ripley, 1995, p. 10) on both sides were exaggerated by mass media reports. Such exaggerated reports blinded the thoughts on alternative course of action. For instance, the governor of Rivers State is said to have celebrated the Supreme Court verdict in favour of his State by castigating the governor of Akwa Ibom State using several innuendoes, including, "God has disgraced him" (Chukwu, 2011). Such media report is not limited to the South-South crises. Elsewhere, Rosenthal, et, al (1991) found a significant demonstration of over bloated press reports akin to war propaganda, which contributed to stress inducing uncertainties in crisis situation.

\section{The Challenges}

Although the National Boundary Commission and the Supreme Court are seen to have performed their constitutionally assigned routine or institutional functions, the crises generated by them have led to wide spread mistrust and distortions in the relationship between the political class, communities and State governments in the South-South geo-political zone. From the analyses of the crises-situation, it is suggestive that the crises have not only weakened the cord that holds interlinkages between the States, but have also exerted significant and disturbing shift in the South-South plan of economic integration. The negative effect of this on collective opinion and responses on matters affecting the South-South zone is worrisome.

In the delineation of boundary in the country, communities are often not consulted. The spirit that influenced the partitioning of Africa to different European powers in 1888 at Berlin seems to have hangover effect on boundary governance decision. Communities therefore remain pawns to be manipulated by the Political class and Political Authorities. For instance, the Bakassi people of South-South, Nigeria were not given opportunity to decide which country should pitch its flag on their soil; even when the case for adjudication was before the International Court of Justice, where human rights are said to be guarded values. Such decision raises questions on the appropriateness of institutional routine actions. It explains suspicions of institutional manipulations and dissatisfaction expressed by affected parties.

The inability to get communities involve in and or their inputs in boundary delineation results in two immediate consequences: the division of one homogeneous community into two under different political authorities, thus leaving a fluid boundary between them; and arbitrariness in the naming of oil wells and field, since there would be no regard to culture and historical titles. The first of the consequences can be seen in the case between Akwa Ibom and Rivers State. The 1976 Nasir's Boundary Commission had sought to split Nkoro Community into Akwa Ibom and Rivers. By so doing, the boundary between Akwa Ibom and Rivers remained very poorly demarcated, and constituted a source of tension and disputation. This is because a State cannot lay claim to a part of a community or it natural endowment except that community belongs to it; and only the NBC has the right to so declare.

The crises between Rivers State and Bayelsa centered on Nembe and Kalabari communities. This is because the Soku oil Wells and field/Oluasiri oil Wells and field are located here. While Rivers State laid claim to the Soku oil Wells, the Bayelsa government claims the Oluasiri oil fields and Wells. In its judgment the Supreme Court ruled that these oil Wells and field are the same, although referred to by the two communities with different names. While the Nembe people of Bayelsa State call the same oil wells and field, Oluasiri, the Kalabari people of Rivers State refer to it as the Soku oil wells (SC/106/2009). This arbitrarily naming of oil wells/fields results in claims and counter claims that followed the boundary delineation. The dispute about these oil wells and fields is not only causing disaffection between Nembe and Kalabari, but has also introduced communal conflict on land dispute. These are not without consequences. The Social capital built over the years through harmonious communal relation by the two communities is already eroding. In a region where Small Arms and Light Weapons' proliferation is yet to be effectively curbed, after several years of militancy, the 
temptation to employ these arms and weapons in communal clash remains very high. The recent withdrawal of Rivers State from the Boundary Mediatory Talk (BMT) initiated by the NBC suggests that the tension is still very high between the two States (Falaranmi, 2013).

Beside the communities, there exist a state-wide alert on the crises. Each government tries to raise the sentiment of State members. This has resulted in deepening social division. The South-South economic integration agenda rests on the shoulders of the South-South Governors. The funding of the BRACED Commission and other programmes, for the benefit of the people in the geo-political zone depend on the political will of the Governors. In the face of these crises, collective approach by the Governors to address problems affecting the South-South zone has not been given priority attention. While at the level of rhetoric, high sounding remarks are made about the existence of the BRACED Commission, the responses in terms of funding of its programmes and activities leave a great yearning gap. State contributions are either not regular or not enough to meet the projects designed by the Commission (Keshi, 2013).

\section{Conclusion and recommendations}

The challenges enumerated in the foregoing paragraphs and their effects are already felt. From our theoretical view point, we understand the highly politicized nature of organizational life of government, and the complexities that influence crisis decision-making, moreso when basic values (as expressed in revenue accruable to States) are threatened. Addressing these crises and the consequences require putting aside all the acrimonies generated by the new boundary delineation and the Supreme Court pronouncement on them. Thus far, it appears that the zone has followed the reactive model in responding to crises. The model swings between judicial pronouncement and political solution. When court judgment considered to provide 'final judicial determination' generates more crises instead, the pendulum swings towards 'political solution' which is short lived. It is time to abandon this model especially since the ideals of the BRACED Commission transcend expedient political considerations.

Several reasons influence our recommendations:

(i). The States in the South-South geo-political zone have similar problems that are remarkably intertwined - oil related environmental pollution, a large pool of unemployed youth, mostly tertiary education graduates, wide spread poverty and a threatened eco-system. Providing solution to these interlinked problem require a jointapproach. One sure way to achieve this is to intensify effort for the realization of the South-South economic integration. It will spur growth in all the South-South States and lift the citizens out of poverty. In this way the challenges from shortfall in federal revenue experienced by States as a result of shift in oil wells related wealth and the lack of fund to embark on individual State development projects can be overcome.

(ii). It is acknowledged in this paper that crisis has many complexities and influence. It can provide opportunities for political ego-boosting, thus serving the ends of the political class, rather than the ordinary citizens. On this note therefore, the South-South Elders Forum (SSEF) should devoid itself from political connections and show leadership in crisis negotiation and settlement, for the benefit of the entire South-South people. The Traditional Rulers in the South-South should also initiate peace meeting to ease the tensions generated by the crisis.

(iii). It is also time to think beyond oil related revenue and dependence by the South-South States. Contemporary thinking in sustainable development justifies this demand. Future generation of the South-South will only remain well off if the present leaders had invested for their future. This can be done in the correct anticipation that oil wells will dry up one day, and or the emergence of a technology driven economy without oil as the energy base. Unfortunately, none of the South-South States has investment fixed along the oil value chain - refinery, tank farm, oil and gas related technology, steel and fabrication, etc - or invest and support researches and technology on a future South-South that will depend less on oil revenue. These alternative thinking and investments will ensure the future of the South-South State, not only within the Nigeria project but also within the globalized economy.

\section{References}

[1]. Akpabio, E. M. \& Akpan, N. S. (2010). Governance and oil politics in Nigeria's Niger Delta: The question of distributive equity. Journal of Human Ecology, 30 (2): 111 -121.

[2]. Akwa Ibom State (AKS) (2012). Akwa Ibom State Government Statement on the 76 oil wells. Uyo: Ministry of Justice.

[3]. BRACED Commission (BC) (2013). Mid Term Review 2013: Port Harcourt.

[4]. Bryder, T. (1998). The human face of politics: Essays on political psychology and politicized culture in the 20th Century. Copenhagen: Copenhagen Political Studies Press.

[5]. Chukwu, I. (2011). How verdict on 86 oil wells affect Rivers, Akwa Ibom economies. Business Day, p.12.

[6]. Coser, L. A. (1977). Masters of Sociological thought, $2^{\text {nd }}$ edn. New York: Harcourt Brace.

[7]. Fiske, S.T. \&Taylor, S. E. (1991). Social cognition 2nd ed. New York: McGraw- Hill.

[8]. Foranmi, F. (2013, February, 31). Rivers vs. Bayelsa: Steer clear of our oil wells, Amachi warns. The Sun Newspaper, p. 2,9

[9]. Folaranmi, F. (2013, March, 14). The Soku/Oluasiri oil wells and oil field: Comments on Bayelsa State response. The Sun Newspaper, p. $12-13$

[10]. Geva, N. \& Mintz, A. (eds) (1997). Decision-making on war and peace: The cognitive-rational debate. Boulder: Rienner. 
[11]. Giddens, A. (2009). Sociology. Gambridge: Polity Press.

[12]. Green, D. \& Shapiro, I. (1994). Pathologies of rational choice theory: A critique of applications in Political Science. New Haven: Yale University Press.

[13]. Habermas, J. (1973/76). Legitimation crisis (translated by T. McCarthy). London: Heinemann.

[14]. Herrfahrdt-Pahle, E \& Pahl-Wostl, C. (2012). Continuity and change in social-ecological system: The role of institutional resilience. Ecology and Society 17(2): 8 -31.

[15]. Ibaba, S. I. (2005). Understanding the Niger Delta crisis. Port Harcourt: Amethyst and Colleagues Publishers.

[16]. Ikoh, M. U. \& Ukpong, E. A. (2013). The Niger Delta crisis: Taming violence beyond amnesty. International Journal of Humanities and Social Science, 17 (3): $146-159$.

[17]. Inokoba, P. K. \& Imbua, D. L. (2010). Vexation and militancy in the Niger Delta: The way forward. Journal of Human ecology, 29 (2): $101-120$

[18]. Janis, I.L. (1982). Groupthink: Psychological studies of policy decisions and fiascoes, 2nd ed. Boston: Houghton Mifflin.

[19]. Janis, I.L. (1989). Crucial decisions: Leadership in policymaking and crisis management. New York: the Free Press.

[20]. King, G., R. Keohane, \& Verba, S. (1994). Designing social inquiry. Princeton: Princeton University Press.

[21]. Lebow, R. \& Stein, J. (1994). We all lost the cold war. Princeton: Princeton University Press.

[22]. Maruyama, N. (1990). Economic Crisis and the 1973 Oil policy in Japan. Wahington D.C.: International Studies Association. 1014 .

[23]. Nisbett, R. \& Ross, L. (1980). Human inference: Strategies and shortcomings of human judgment. Englewood Cliffs, NJ: Prentice Hall.

[24]. North, D. C. (1993). Institutional change: A framework of analysis, In S. E. Sjostrand (ed.).(pp.: 35 - 46). Institutional change: Theory and empirical; findings. New York: Armonk.

[25]. Okonta, I. O. D. (2001). Where vulture feast: Forty years of shell in the Niger Delta. Ibadan: Kraft Books Ltd.

[26]. Omeje, K. (2006). Petrolbusiness and security threats in the Niger Delta, Nigeria. Current Sociology, 54 (3), pp. 477 - 499.

[27]. Omotoso, P. K. (2012, March, 5). Brothers at war. Daily Mirror, p. 17.

[28]. Powell, W. \& DiMaggio, P. (eds.) (1991). The New Institutionalism in organizational analysis. Chicago: The University of Chicago Press.

[29]. Purkitt, H. (1992). Political decision making in small groups. In E. Singer and V.P. Hudson (eds). Political psychology and foreign policy, (pp. 219-245). Boulder: Westview Press.

[30]. Richardson, J.L. (1994) Crisis Diplomacy. New York: Cambridge University Press.

[31]. Ripley, B. (1995). Cognition, culture, and bureaucratic politics. In L. Neack, J. Hey and P. Haney (ed. Foreign policy analysis: The second generation (pp.85-97). Englewood Cliffs, N.J.: Prentice-Hall.

[32]. Rosenthal, U., t Hart, P. \& Kouzmin, A. (1991) "The bureau-politics of crisis management." Public Administration, 69 (2): 211 233.

[33]. Sagay, I, (2004, April 5). Onshore/offshore dichotomy: How government deceived Niger Delta people. Daily Sun, p.16.

[34]. SC/106/2009: Attorney general of Rivers State vs. Attorney general of Bayelsa State and Anors.

[35]. Schaefer, R. T. 92008). Sociology matters. Boston: McGraw-Hill.

[36]. Schmitt, C. (1996). The concept of the crisis and politics (transl. by G. Schwab). Chicago: University of Chicago Press.

[37]. Snyder, R.C, Bruck, H. \& Sapin, B., eds. (1963). Crisis situation and decision-making. New York: The Free Press.

[38]. Stern, E. K. (2003). Crisis decisionmaking: A cognitive institutional approach. Stockholm: Swedish National Defence College.

[39]. Udoh, R. K. (2010). Niger Delta and Regional Development. In S. O. Akande and A. J. Kumuyi (eds). Nigeria at 50. (409 - 426). Ibadan: NISER.

[40]. Ujah, E, Onoyume, J. \& Oyadongha, S. (2012, November, 1). Rivers vs. Bayelsa: Steer clear of our oil wells, amaechi warns. Vanguard Newspaper, p. 8

[41]. Ukpong, E. A. (ed.) (2012). Integrating South - South Nigeria for Sustainable Development. Port Harcourt: BRACED Commission.

[42]. Ukpong, E. A. (ed.) (2009). Braced for Global Competitiveness. Lagos: Ekidio Limited.

[43]. Vertzberger, Y. (1990) The World in Their Minds: Information processing, cognition, and perception in foreign policy decisionmaking. Stanford, CA: Stanford University Press 